\title{
Reliability and Validity of the Korean Version of the Pain Disability Questionnaire
}

\author{
Jisun Yoon, $\mathrm{MD}^{1}$, Kyoung Hyo Choi, MD, PhD ${ }^{1}$, Tae Woo Kim, $\mathrm{MD}^{2}$, Seo Yon Yang, $\mathrm{MD}^{1}$, Mi Kyung Sim, $\mathrm{MD}^{1}$
}

${ }^{1}$ Department of Rehabilitation Medicine, Asan Medical Center, University of Ulsan College of Medicine, Seoul; ${ }^{2}$ Department of Rehabilitation Medicine, Seoul St. Mary's Hospital, The Catholic University of Korea College of Medicine, Seoul, Korea

Objective To translate the English version of the Pain Disability Questionnaire (PDQ) into Korean and to investigate the reliability and validity of the Korean version of the PDQ (K-PDQ) in patients suffering chronic disabling musculoskeletal disorders (CDMDs).

Methods The English version of the PDQ was translated into Korean. Ten patients with CDMDs were randomly selected for a pilot study to assess the comprehensibility of the pre-final version. One hundred and thirty-nine patients suffering from CDMDs for more than 3 months were enrolled in this study. Follow-up questionnaires were obtained to examine the test-retest reliability. Concurrent validity was evaluated by comparing the K-PDQ with the visual analogue scale (VAS). Construct validity was evaluated by comparing the K-PDQ with the brief form of the World Health Organization quality of life assessment instrument (WHOQOL-BREF) using Pearson correlation coefficient. Reliability was assessed using the intraclass correlation coefficient (ICC), and internal consistency was determined by Cronbach's alpha.

Results Test-retest reliability was assessed in 70 patients, with an average time interval of 12 days. The ICC was 0.958 $(\mathrm{p}<0.001)$. Internal consistency reached Cronbach's alpha of 0.933 for the functional component and 0.870 for the psychosocial component. The correlation coefficient for the K-PDQ when compared with the VAS was 0.834 in the first assessment and 0.831 in the second assessment. All domains of the WHOQOL-BREF showed a significant negative correlation with the K-PDQ.

Conclusion The K-PDQ is a reliable and valid instrument for measuring disability and can be used to assess disability and treatment outcomes in Korean patients with CDMD.

Keywords Korean version pain disability questionnaire (K-PDQ), Validity, Reliability, Treatment outcome

Received April 24, 2013; Accepted August 4, 2013

Corresponding author: Kyoung Hyo Choi

Department of Rehabilitation Medicine, Asan Medical Center, University of Ulsan College of Medicine, 88 Olympic-ro 43-gil, Songpa-gu, Seoul 138-736, Korea

Tel: +82-2-3010-3800, Fax: +82-2-3010-6964, E-mail: khchoi@amc.seoul.kr

(c) This is an open-access article distributed under the terms of the Creative Commons Attribution Non-Commercial License (http://creativecommons. org/licenses/by-nc/3.0) which permits unrestricted noncommercial use, distribution, and reproduction in any medium, provided the original work is properly cited.

Copyright $\odot 2013$ by Korean Academy of Rehabilitation Medicine

\section{INTRODUCTION}

Musculoskeletal disorders are a major public health problem in developed countries [1], mainly due to the increased treatment costs and the impact on the quality of life (QoL) from the reduction of activity due to pain [2]. Thus, there is increasing interest in identifying the demographic, psychological, and socioeconomic variables that affect chronicity and treatment outcomes for those suffering from chronic disabling musculoskeletal dis- 
orders (CDMDs) [3-5]. To effectively evaluate treatment outcomes, one needs to measure not only the functional status but also the clinical outcomes.

Therefore, the Pain Disability Questionnaire (PDQ) was specially developed for evaluating the clinical outcome in CDMD patients. The PDQ is an objective, quantifiable, patient-oriented, and self-reporting instrument that takes physical, psychological, and socioeconomic parameters into account [6-8]. The PDQ shows a strong correlation with a wide variety of physical and psychosocial indices, including the SF-36, the Hamilton-D State-Trait Anxiety Scale, the Beck Depression Inventory (BDI), the visual analogue scale (VAS), and the Oswestry Disability Index (ODI), and the Roland-Morris Disability Questionnaire (RMDQ) [7]. Unlike most other tools, the PDQ can be used to evaluate chronic disorders of the upper extremities and lower extremities as well as low back pain. Kopec [9] reported that the majority of the currently available disability indices focus on physical function, with minimal attention paid to psychosocial issues. Recent studies show that psychosocial variables play an integral role in the development and maintenance of chronic pain and disability [10-12].

The PDQ is comprised of 15 items that are divided into two components. The 9 items (1, 2, 3, 4, 5, 6, 7, 12, and 13) that reflect different aspects of the functional status and disability are pain intensity, self-care, lifting, walking, sitting, standing, sleeping, participation in social life, and traveling. The 6 items $(8,9,10,11,14$, and 15) that reflect different aspects of the psychological status are financial changes, dependence on medicines, visits to the hospital, personal relationships, mood change, and psychological problems.

Each item is scored from 0 to 10 using a $10 \mathrm{~cm}$ VAS format, with higher values representing greater disability. The functional component has a maximum score of 90 points and the psychosocial component a maximum score of 60 points. The total score of the PDQ ranges from 0 to 150 . The PDQ scores classify the degree of disability as follows: 0 , no disability; $1-70$, mild disability; $71-100$, moderate disability; 101-130, severe disability; and 131150, extreme disability.

If the data are to be comparable, the self-reported measurement tools must be adapted to reflect the culture and the language of the patients that use them. As such, several of the self-reported measurement tools like the
ODI and the RMDQ that are used to evaluate functional status, disability, and clinical outcomes have been translated into Korean, and also validation studies have been performed. In order to assess the effectiveness of applying the PDQ, it must be translated into Korean because the background and culture of Korean patients are very different from those in English-speaking countries. The aim of this study was to translate the original (English) version of the PDQ into Korean and to investigate the reliability and validity of the Korean version of the PDQ (K-PDQ) in patients with CDMD.

\section{MATERIALS AND METHODS}

\section{Patients}

A total of 139 CDMD patients were recruited from the outpatient clinic at the Department of Rehabilitation Medicine of Asan Medical Center between March 2011 and March 2012. The inclusion criteria were as follows: 1) patients were currently experiencing musculoskeletal pain, either with or without neurological signs, 2) patients could complete the Korean version of the MiniMental State Examination and had obtained a score over 24, and 3) patients had suffered from CDMD for more than 3 months. The exclusion criteria were as follows: 1) pain due to acute trauma or medical disease, 2) medical instability, and 3) cognitive impairment and/or psychiatric problems.

\section{The Korean version of the Pain Disability Questionnaire}

The original version of the PDQ was translated into Korean in accordance with the published guidelines [13]. The translation was performed by four independent translators in five stages (Fig. 1). 1) Two translators performed the forward translation. One translator was a physician and the other was a professional translator blinded to the purpose of the study. 2) These two translators then compared the translated version with the original and a synthesis of the translated version was performed. 3) Two translators who were fluent in both English and Korean performed a back translation of the synthetic version into English. Both of the translators were not aware of the prior translation. 4) The K-PDQ was reviewed by an expert committee comprising the two forward translators, the two back translators, a doctor specializing in medical rehabilitation, and a methodologist. The committee 


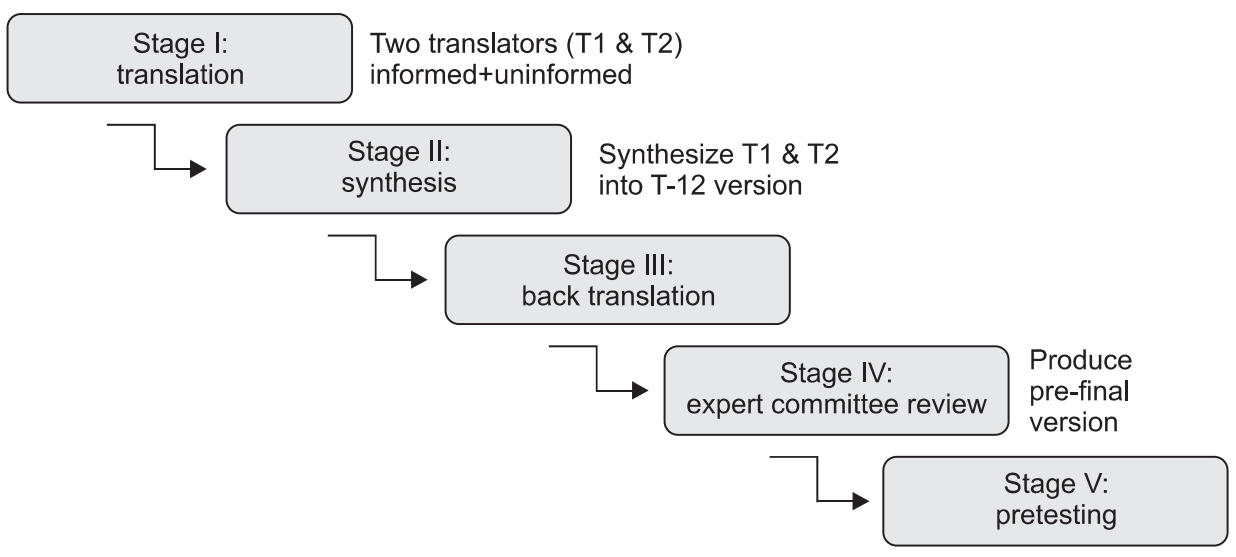

Fig. 1. The five stages involved in the translation of the original Pain Disability Questionnaire into Korean. reviewed the forward translation, the backward translation, and the original version of the PDQ. They then formulated a pre-final version of the K-PDQ. 5) The prefinal version was tested before it was used in the present study. Ten patients with CDMDs admitted to the Department of Rehabilitation Medicine or attending the outpatient service were randomly selected for a pilot study to assess the comprehensibility of the pre-final version. The patients reported the average time taken to complete the questionnaire, whether they had difficulty with any of the concepts, and whether the questionnaire was relevant to them.

\section{Reliability and validity testing}

The K-PDQ (Appendix 1) was completed by 139 patients with chronic pain. The patients also recorded their pain levels using the VAS. The VAS score is determined by measuring the distance $(\mathrm{mm})$ on a $10-\mathrm{cm}$ line ruler providing a range of scores from $0-100[14,15]$. All patients were asked to complete a second K-PDQ between one to two weeks after the first K-PDQ. Test-retest reliability was measured by comparing the results of the first and second administration of the K-PDQ. Seventy patients among all the participants completed the second questionnaire. Reliability was measured using the intraclass correlation coefficient (ICC). Concurrent validity refers to whether a test correlates well with a measure that has previously been validated. It was measured by comparing the responses of the K-PDQ with the results of the VAS score. The brief form of the World Health Organization quality of life assessment instrument (WHOQOL-BREF) is a QoL assessment tool developed by the WHOQOL group and is available in 19 different languages including Korean [16]. It comprises 26 questions and yields four domain scores, each of which represents a person's perception of their QoL. The four domains are physical health, psychological health, social relationships, and environment [17]. A higher score reflects a better QoL. Construct validity represent whether a scale measures or correlates with the theorized psychological scientific construct that it purports to measure. Construct validity was measured by comparing the responses of the K-PDQ with the results of the WHOQOL-BREF scores. The internal consistency of each question within the K-PDQ was assessed using Cronbach's alpha.

\section{Statistical analysis}

All variables were analyzed using the Statistical Package for the Social Sciences (SPSS) ver. 18.0 (SPSS Inc., Chicago, IL, USA). Statistical significance was defined as a p-value of $<0.05$. Test-retest reliability was measured using the ICC which evidences stability of the instrument if ICC $\geq 0.75$ [8]. Concurrent validity and construct validity were measured by Pearson correlation coefficient, and values close to 0.30 were considered as satisfactory, between 0.30 and 0.50 as moderate, and over 0.50 as strong. Cronbach's alpha was used to evaluate the internal consistency. A Cronbach's alpha coefficient of over 0.70 was considered as satisfactory evidence of internal consistency [6].

\section{RESULTS}

\section{Patient demographics}

One hundred and thirty-nine patients (50 males and 89 females; mean age, 59 years) with CDMD were recruited and 70 patients among 139 patients completed the second K-PDQ questionnaire. The patient demographics are presented in Table 1 . The mean duration of pain was 
22 months. The mean initial K-PDQ score was 60.8 (mild disability) and the initial mean VAS score was 56.6.

\section{Reliability and validity of the K-PDO}

Test-retest reliability was assessed for the 70 patients who filled out the second questionnaire. There were no statistically significant differences in sex, age, and pain duration between the group completing the retest $(n=70)$ and the group that completed the initial questionnaire $(\mathrm{n}=139)$. The overall test-retest ICC was 0.958 (95\% confidence interval [CI], 0.931-0.974). The test-retest ICC for

Table 1. Baseline characteristics of subjects $(n=139)$

\begin{tabular}{|lc|}
\hline Characteristic & Value \\
\hline Sex (male:female) & $50: 89$ \\
\hline Age (yr) & $54.5 \pm 13.2$ \\
\hline Pain location & \\
\hline Back & 54 \\
\hline Shoulder & 41 \\
\hline Lower extremity & 19 \\
\hline Others & 13 \\
\hline Neck & 12 \\
\hline Duration (mo) & $22.0 \pm 22.6$ \\
\hline K-PDQ score & $60.8 \pm 31.2$ \\
\hline VAS score & $56.6 \pm 20.0$ \\
\hline
\end{tabular}

Values are presented as mean \pm standard deviation or number.

K-PDQ, Korean version of the Pain Disability Questionnaire; VAS, visual analogue scale.

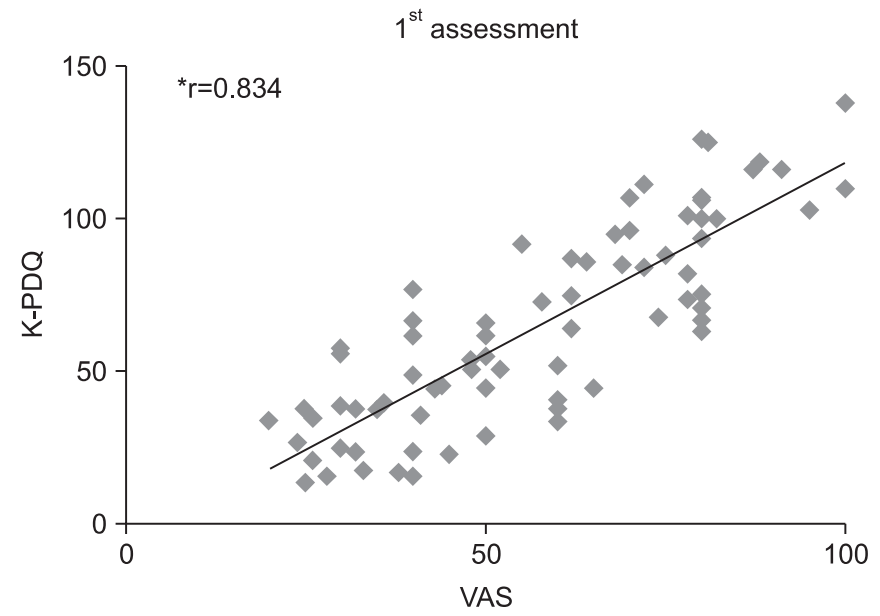

reliability was 0.950 (95\% CI, $0.919-0.970 ; \mathrm{p}<0.001)$ for the functional component and 0.908 for the psychosocial component (95\% CI, 0.852-0.943; p<0.001) (Table 2). Overall, the K-PDQ showed excellent test-retest reliability (ICC $>0.75, \mathrm{p}<0.001$ ).

The mean score for the second set of results of VAS was $55.6 \pm 19.1$ and for the second set of responses of the KPDQ was $62.8 \pm 29.8$ (mild disability). The concurrent validity of the K-PDQ when compared with the VAS showed a significant positive correlation in both assessments (first assessment, $\mathrm{r}=0.834, \mathrm{p}<0.001$; second assessment, $\mathrm{r}=0.831$, $\mathrm{p}<0.001$; by Pearson correlation) (Fig. 2).

The concurrent validity for the functional component of the K-PDQ was 0.808 in the first assessment and 0.804 in the second assessment. And that for the psychosocial component was 0.783 in the first assessment and 0.748 in the second assessment. Although the validity of the functional component was slightly higher than that of the psychosocial component, each component showed a strong positive correlation with the VAS ( $r>0.7)$.

Table 2. Test-retest reliability of the Korean version of the Pain Disability Questionnaire

\begin{tabular}{lccc}
\hline & ICC & $\mathbf{9 5 \%}$ CI & p-value \\
\hline Total & 0.958 & $0.931-0.974$ & $<0.001$ \\
Functional & 0.950 & $0.919-0.970$ & $<0.001$ \\
\hline Psychosocial & 0.908 & $0.852-0.943$ & $<0.001$ \\
\hline
\end{tabular}

ICC, intraclass correlation coefficient; CI, confidence interval.

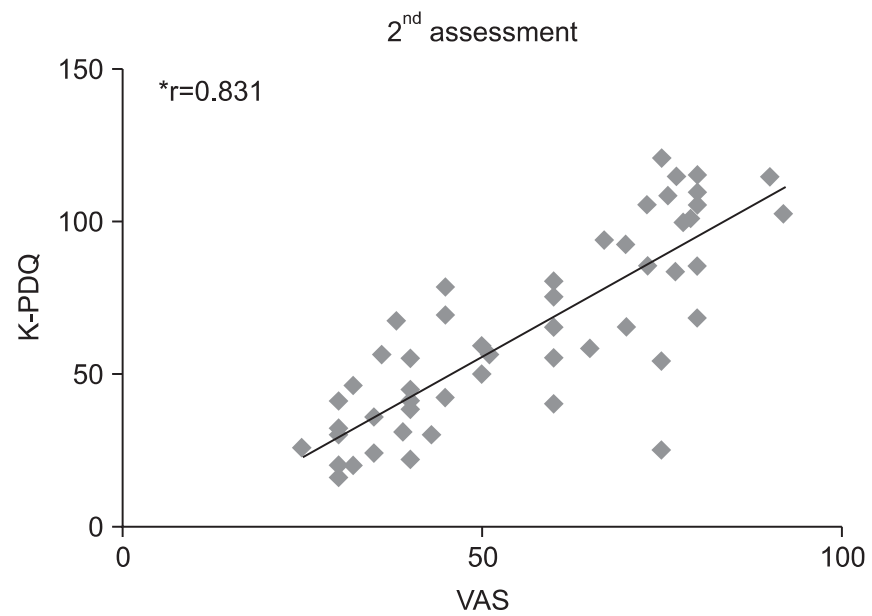

Fig. 2. Concurrent validity of the Korean version of the Pain Disability Questionnaire (K-PDQ) when compared with the visual analogue scale (VAS). * $p<0.001$, Pearson correlation coefficient. 
The correlation between the four domains of the WHOQOL-BREF and those of the K-PDQ is shown in Table 3. Construct validity between the K-PDQ and the WHOQOLBREF showed a significant negative correlation in almost all of the domains ( $\mathrm{r}=-0.473$ to $-0.749 ; \mathrm{p}<0.001$ ). In particular, the correlation between the functional component of the K-PDQ and the physical component of the WHOQOLBREF was higher than that between any of the other domains. The correlation coefficients between the physical health and social domains of the WHOQOL-BREF and the K-PDQ were $r=-0.749(\mathrm{p}<0.01)$ and $\mathrm{r}=-0.584(\mathrm{p}<0.01)$, respectively. The correlation coefficients between the K-PDQ and the psychological health and environment domains of the WHOQOL-BREF were low ( $\mathrm{r}=-0.542$ and $\mathrm{r}=-0.501$, respectively), but still statistically significant $(\mathrm{p}<0.01)$.

The internal consistency of the K-PDQ is illustrated in Table 4. Cronbach's alpha values represent the internal consistency when each of the questions is excluded from each of the domains. Cronbach's alpha value for each of the items of the K-PDQ was $>0.900$. We also analyzed the reliability and validity of the K-PDQ for assessing back and shoulder pain alone. The results showed similar reliability and validity to those obtained when using the complete K-PDQ. Test-retest reliability, internal consistency, construct validity, and concurrent validity of the K-PDQ were similar to those of the original version (Table 5).

\section{DISCUSSION}

The aim of the present study was to construct a Korean version of the PDQ and then examine its reliability and

Table 3. Construct validity of the K-PDQ when compared with the WHOQOL-BREF

\begin{tabular}{llll}
\hline & $\begin{array}{c}\text { K-PDQ } \\
\text { (total) }\end{array}$ & Functional & $\begin{array}{c}\text { Psycho- } \\
\text { social }\end{array}$ \\
\hline $\begin{array}{l}\text { WHOQOL-BREF } \\
\text { (total) }\end{array}$ & $-0.699^{*}$ & $-0.669^{*}$ & $-0.668^{*}$ \\
\hline Physical & & & \\
\hline Psychological & $-0.749^{*}$ & $-0.730^{*}$ & $-0.697^{*}$ \\
\hline Social relationship & $-0.542^{*}$ & $-0.507^{*}$ & $-0.536^{*}$ \\
\hline Environmental & $-0.501^{*}$ & $-0.555^{*}$ & $-0.565^{*}$ \\
\hline
\end{tabular}

K-PDQ, Korean version of the Pain Disability Questionnaire; WHOQOL-BREF, World Health Organization quality of life assessment.

${ }^{*} \mathrm{p}<0.05$, Pearson correlation coefficient. validity. A rigorous adaptation and translation process was undertaken to avoid distorting the meaning and structure of the original PDQ. The structure of the K-PDQ was the same as that of the original version and all 15 items were retained. The results showed that the K-PDQ is a reliable and valid instrument for measuring disability and clinical outcomes in Korean patients with CDMD.

Table 4. Internal consistency of the Korean version of the Pain Disability Questionnaire

\begin{tabular}{|cc|}
\hline Component (score) & Cronbach's alpha \\
\hline Function (90) & $0.945^{*}$ \\
\hline Q1: work capacity & $0.944^{*}$ \\
\hline Q2: personal care & $0.945^{*}$ \\
\hline Q3: mobility, traveling & $0.943^{*}$ \\
\hline Q4: movement, sitting, standing & $0.946^{*}$ \\
\hline Q5: lifting, reaching, grasping & $0.947^{*}$ \\
\hline Q6: posturing & $0.943^{*}$ \\
\hline Q7: walking, running & $0.943^{*}$ \\
\hline Q12: recreational activity, hobby & $0.944^{*}$ \\
\hline Q13: dependence of ADL & $0.943^{*}$ \\
\hline Psychosocial (60) & $0.927^{*}$ \\
\hline Q8: income change & $0.905^{*}$ \\
\hline Q9: dependence on medicine & $0.948^{*}$ \\
\hline Q10: visiting hospital & $0.936^{*}$ \\
\hline Q11: personal relationship & $0.922^{*}$ \\
\hline Q14: mood change & $0.935^{*}$ \\
\hline Q15: psychological problem & $0.944^{*}$ \\
\hline Total (150) & $0.938^{*}$ \\
\hline
\end{tabular}

ADL, activities of daily living. ${ }^{*} \mathrm{p}<0.05$.

Table 5. Reliability and validity of the K-PDQ compared with the original version

\begin{tabular}{lcc}
\hline & $\begin{array}{c}\text { PDQ } \\
\text { (original) }\end{array}$ & K-PDQ \\
\hline Test-retest reliability & 0.94 to 0.98 & 0.91 to 0.96 \\
Internal consistency & 0.90 to 0.96 & 0.90 to 0.95 \\
\hline Concurrent validity (VAS) & 0.64 to 0.81 & 0.83 \\
\hline $\begin{array}{c}\text { Construct validity (SF-36) } \\
\text { Construct validity } \\
\text { (WHOQOL-BREF) }\end{array}$ & -0.22 to -0.71 & - \\
\hline
\end{tabular}

K-PDQ, Korean version of the Pain Disability Questionnaire; VAS, visual analogue scale; WHOQOL-BREF, World Health Organization quality of life assessment. 
Also the K-PDQ is a simple disability measurement tool and feasible to apply and easy to understand in patients with chronic pain.

The reliability of the K-PDQ was evaluated using the test-retest method, with a mean time interval of 12 days between assessments. There is no consensus in the literature regarding the most effective interval for test-retesting. This is because of natural fluctuations in pain perception, which are associated with the "memory effect". Johansson and Lindberg [18] suggest that, in the absence of a specific intervention, the clinical status of a patient suffering chronic pain is unlikely to change appreciably in 1-2 weeks. Therefore, we used a 1-2 week time interval between the first and second administrations of the K-PDQ, during which the patients' medications and physical treatment programs were unchanged. Test-retest reliability of the K-PDQ was excellent and similar to the original version of the PDQ.

In a previous study, the PDQ showed similar reliability and validity to the ODI and the RMDQ, and accurately reflected the psychometric factors in CDMDs patients [7]. A previous study showed that the items comprising the functional component of the PDQ showed a very strong correlation with both the VAS and the ODI [7]. The same study found that the functional component also showed a strong association with other measures of physical function, such as the SF-36 and the physical cumulative score. Similarly, the items comprising the psychosocial component showed a very strong correlation with the BDI, the Hamilton Rating Scale for Depression, the SF-36, the Mental Health Composite, and the Minnesota Multiphasic Personality Inventory-2 [7].

The scores for the functional component of the K-PDQ showed a strong correlation with the VAS and the physical component of the WHOQOL-BREF. The scores for the psychosocial component of the K-PDQ also showed a strong correlation with the VAS and the WHOQOL-BREF (psychological, social relationships, and environmental domains). However, the correlation between the K-PDQ and the psychological health and environment domains of the WHOQOL-BREF was low, but still statistically significant. The reliability and validity of the K-PDQ were not inferior in all aspects when compared with the original version.

The previous study also showed that the psychometric domains of the PDQ were a more robust measurement of the CDMC than the ODI, MVAS, or RMDQ [7]. However, the present study found that the functional component of the K-PDQ showed higher reliability and validity than the psychosocial component. This may be because the mean pain duration of participants in this study was shorter (22 months) than that reported in other studies (36 months), and the mean K-PDQ score was 60.8 (mild disability). Therefore, the present study may underestimate the psychological component, which tends to increase with pain duration.

The ODI and the RMDQ were designed specifically for patients with low back pain or spinal disorders, rather than CDMD $[19,20]$. Unlike the ODI and RMDQ for low back pain or the neck disability index for neck pain, which evaluate disability due to pain at specific sites, the K-PDQ can measure disability caused by general musculoskeletal disorders. Therefore, we examined whether the location of the pain affected the reliability and validity of the K-PDQ. We found that the reliability and validity for individual pain sites ( 54 patients with back pain and 41 patients with shoulder pain) were similar to those obtained using the complete K-PDQ.

This study has several limitations. First, there were many more female than male study subjects (89 vs. 50 ). A previous study of 85,052 adults, spanning 17 countries across six continents, found that the prevalence of chronic pain was higher among females $(45 \%)$ than males (31\%), and that females suffering from chronic pain showed a higher incidence of depression [21]. In one study, women reported significantly higher "worst pain" and "current pain" scores, although there were no differences in the "least pain" scores [22]. The greater number of females in the present study may have affected the psychosocial component of the K-PDQ [21-23]. A second limitation is that the patients in the present study reported their level of disability as "mild". Third, pain was localized to the back or shoulder in approximately $68 \%$ of the current patients. Finally, we did not examine the responsiveness of the K-PDQ.

In conclusion, this study reports the successful translation of the PDQ according to internationally accepted methodological standards. The K-PDQ shows acceptable reliability, concurrent validity, and construct validity and will be useful for measuring disability and clinical outcomes in Korean patients with chronic musculoskeletal disorders. 


\section{CONFLICT OF INTEREST}

No potential conflict of interest relevant to this article was reported.

\section{REFERENCES}

1. Bergman S. Public health perspective: how to improve the musculoskeletal health of the population. Best Pract Res Clin Rheumatol 2007;21:191-204.

2. Ricci JA, Stewart WF, Chee E, Leotta C, Foley K, Hochberg MC. Back pain exacerbations and lost productive time costs in United States workers. Spine (Phila Pa 1976) 2006;31:3052-60.

3. Gatchel RJ, Polatin PB, Mayer TG. The dominant role of psychosocial risk factors in the development of chronic low back pain disability. Spine (Phila Pa 1976) 1995;20:2702-9.

4. Polatin PB, Gatchel RJ, Barnes D, Mayer H, Arens C, Mayer TG. A psychosociomedical prediction model of response to treatment by chronically disabled workers with low-back pain. Spine (Phila Pa 1976) 1989;14:956-61.

5. Gatchel RJ, Polatin PB, Kinney RK. Predicting outcome of chronic back pain using clinical predictors of psychopathology: a prospective analysis. Health Psychol 1995;14:415-20.

6. Gatchel RJ, Mayer TG, Theodore BR. The pain disability questionnaire: relationship to one-year functional and psychosocial rehabilitation outcomes. J Occup Rehabil 2006;16:75-94.

7. Anagnostis C, Gatchel RJ, Mayer TG. The pain disability questionnaire: a new psychometrically sound measure for chronic musculoskeletal disorders. Spine (Phila Pa 1976) 2004;29:2290-302.

8. Giordano PC, Alexandre NM, Rodrigues RC, Coluci MZ. The Pain Disability Questionnaire: a reliability and validity study. Rev Lat Am Enfermagem 2012;20:76-83.

9. Kopec JA. Measuring functional outcomes in persons with back pain: a review of back-specific questionnaires. Spine (Phila Pa 1976) 2000;25:3110-4.

10. Polatin PB, Kinney RK, Gatchel RJ, Lillo E, Mayer TG. Psychiatric illness and chronic low-back pain. The mind and the spine: which goes first? Spine (Phila Pa 1976) 1993;18:66-71.
11. Dersh J, Gatchel RJ, Polatin P. Chronic spinal disorders and psychopathology: research findings and theoretical considerations. Spine J 2001;1:88-94.

12. Dersh J, Gatchel RJ, Polatin P, Mayer T. Prevalence of psychiatric disorders in patients with chronic workrelated musculoskeletal pain disability. J Occup Environ Med 2002;44:459-68.

13. Beaton DE, Bombardier C, Guillemin F, Ferraz MB. Guidelines for the process of cross-cultural adaptation of self-report measures. Spine (Phila Pa 1976) 2000;25:3186-91.

14. Hawker GA, Mian S, Kendzerska T, French M. Measures of adult pain: Visual Analog Scale for Pain (VAS Pain), Numeric Rating Scale for Pain (NRS Pain), McGill Pain Questionnaire (MPQ), Short-Form McGill Pain Questionnaire (SF-MPQ), Chronic Pain Grade Scale (CPGS), Short Form-36 Bodily Pain Scale (SF-36 BPS), and Measure of Intermittent and Constant Osteoarthritis Pain (ICOAP). Arthritis Care Res (Hoboken) 2011;63 Suppl 11:S240-52.

15. Jensen MP, Karoly P, Braver S. The measurement of clinical pain intensity: a comparison of six methods. Pain 1986;27:117-26.

16. Min SK, Kim KI, Lee CI, Jung YC, Suh SY, Kim DK. Development of the Korean versions of WHO Quality of Life scale and WHOQOL-BREF. Qual Life Res 2002;11:593-600.

17. The WHOQOL Group. Development of the World Health Organization WHOQOL-BREF quality of life assessment. Psychol Med 1998;28:551-8.

18. Johansson E, Lindberg P. Subacute and chronic low back pain: reliability and validity of a Swedish version of the Roland and Morris Disability Questionnaire. Scand J Rehabil Med 1998;30:139-43.

19. Liu H, Tao H, Luo Z. Validation of the simplified Chinese version of the Oswestry Disability Index. Spine (Phila Pa 1976) 2009;34:1211-6.

20. Lee JS, Lee DH, Suh KT, Kim JI, Lim JM, Goh TS. Validation of the Korean version of the Roland-Morris Disability Questionnaire. Eur Spine J 2011;20:2115-9.

21. Tsang A, Von Korff M, Lee S, Alonso J, Karam E, Angermeyer MC, et al. Common chronic pain conditions in developed and developing countries: gender and age differences and comorbidity with depressionanxiety disorders. J Pain 2008;9:883-91.

22. Rustoen T, Wahl AK, Hanestad BR, Lerdal A, Paul S, 
Miaskowski C. Gender differences in chronic pain: findings from a population-based study of Norwegian adults. Pain Manag Nurs 2004;5:105-17.

23. Fillingim RB, King CD, Ribeiro-Dasilva MC, Rahim-
Williams B, Riley JL 3rd. Sex, gender, and pain: a review of recent clinical and experimental findings. J Pain 2009;10:447-85. 
Appendix 1. The Korean version of the pain disability questionnaire (K-PDQ)

\section{통증장애 설문지(K-PDQ)}

이름: 등록번호: 날짜: $\quad \underline{\text { VAS: }}$

지금 현재 통증이 일상생활에 미치는 정도를 직선 위에 "X" 표시해 주세요.

직선의 왼쪽 끝은 통증이 전혀 문제가 되지 않는 상태, 오른쪽 끝은 더 이상 상상할 수 없을 정도로 심각한 문제가 되는 상태를 의미합니다.

통증 정도가 변하는 경우 통증이 약할 때와 심할 때로 한 직선에 두 군데 "X" 표시하세요.

다음의 모든 질문에 답하여야 합니다.

1) 통증이 당신의 일상 생활(집안일과 직장일 모두)에 어느 정도로 문제가 되나요?

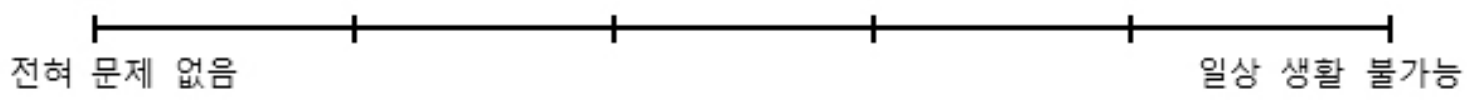

2) 통증 때문에 개인 위생활동(세수하기, 손 씻기, 옷 입기 등)에 불편함이 있나요?

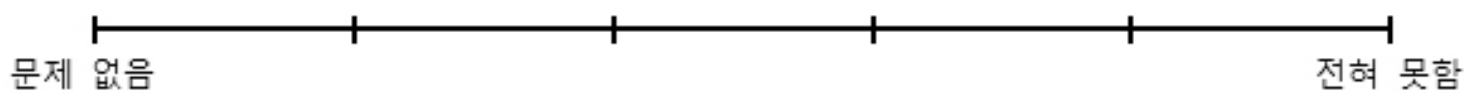

3) 통증 때문에 이동하는데 불편함이 있나요? (장거리, 단거리 이동을 모두 포함)

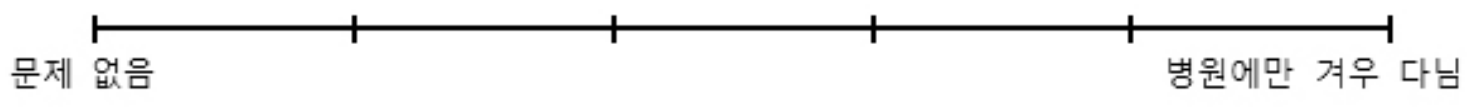

4) 통증 때문에 앉고 서는데 불편함이 있나요?

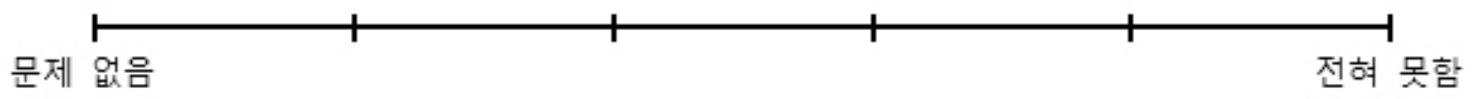

5) 통증 때문에 물건을 잡기 위해 손을 뻗거나, 물건을 손으로 쥐거나, 머리위로 물건을 들어 올리는 등의 행동에 제약이 있나요?

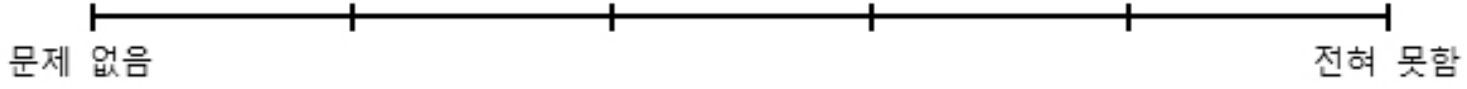

6) 통증 때문에 바닥에 놓여 있는 물건을 들거나, 쪼그려 앉는 행동에 제약이 있나요?

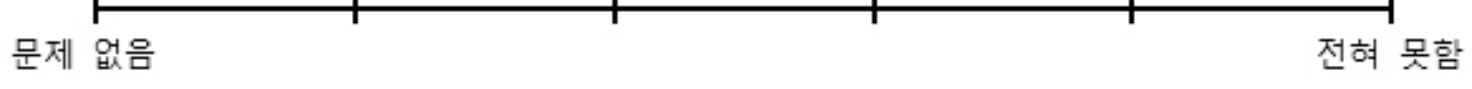


7) 통증 때문에 걷거나 뛰는데 제약이 있나요?

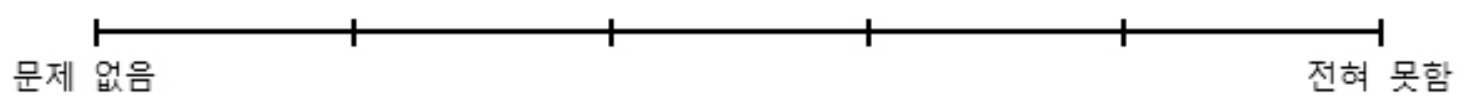

8) 통증이 시작된 이후 월 수입에 변화가 있나요?

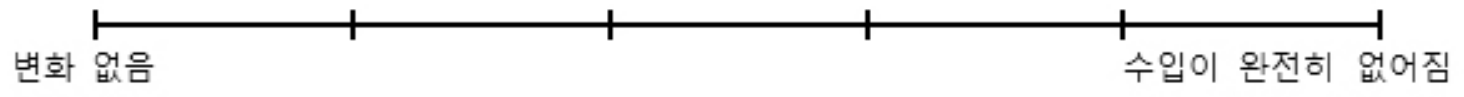

9) 통증 조절을 위해 약을 얼마나 복용하고 있나요?

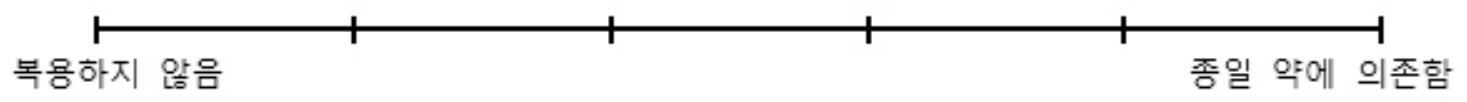

10) 통증 때문에 얼마나 자주 병원에 가나요?

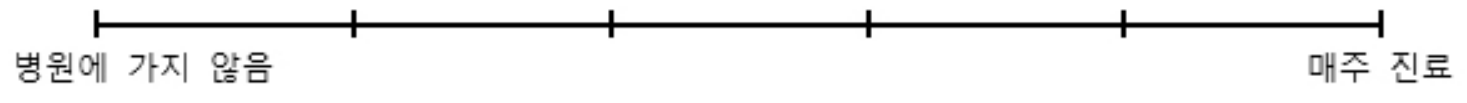

11) 통증이 사람(직장동료, 친구나 친척 등)을 만나는 데 영향을 주나요?

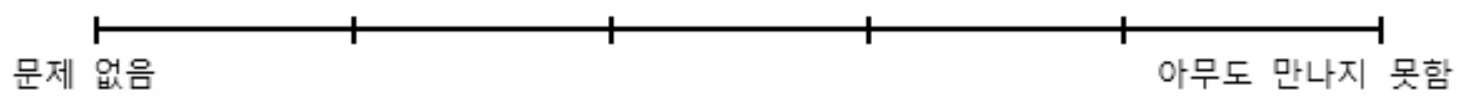

12) 통증이 당신의 취미활동(독서, 음악감상 등)이나 여가활동(등산, 산책 등)에 영향을 주나 요?

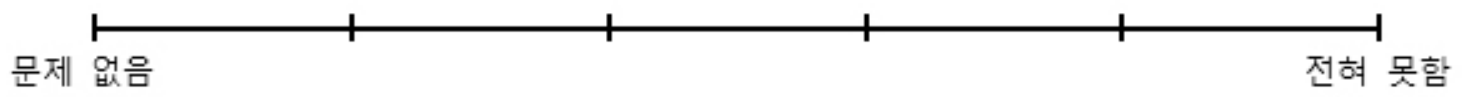

13) 통증 때문에 집안일이나 직장 일에 가족이나 동료의 도움이 필요하나요?

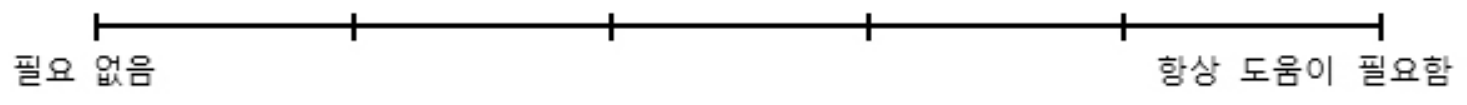

14) 통증 때문에 이전보다 더 우울하거나 긴장되고 불안한 기분이 드나요?

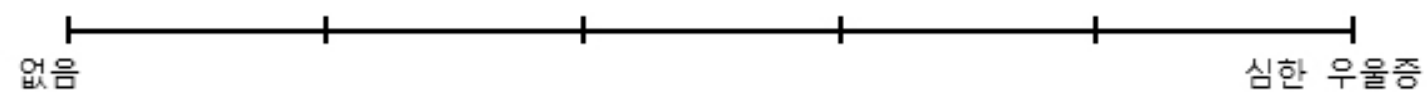

15) 통증 때문에 가족과 사회적 관계에 지장을 주는 감정 문제가 생겼나요?

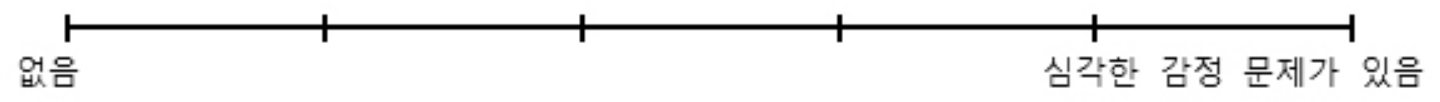

